\title{
THE UNITED STATES AND CANADIAN RESPONSES TO THE FEMINIST ATTACK ON \\ PORNOGRAPHY: A PERSPECTIVE FROM THE HISTORY OF OBSCENITY
}

\author{
Kevin W. Saunders*
}

In April 1984, the city of Indianapolis enacted an ordinance prohibiting

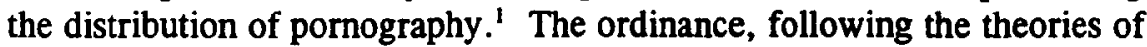
Catharine Mackinnon and Andrea Dworkin, went beyond addressing materials considered legally obscene. The ordinance targeted matter that combined sexually explicit images with depictions of women as enjoying pain, assault, humiliation or certain other forms of degradation.

The ordinance had a rather short life. The Association of American Booksellers, the Association of American Publishers, a local video rental store, a resident of Indianapolis, and other plaintiffs challenged its constitutionality. In November 1984, the federal district court held it unconstitutional. ${ }^{2}$ This position was affirmed by the United States Court of Appeals for the Seventh Circuit in August 1985 in a case titled American Booksellers Association v. Hudnut. ${ }^{3}$ The Supreme Court of the United States affirmed without issuing an opinion. ${ }^{4}$

While the ordinance may have been short-lived, the scholarly controversy it engendered has had a much longer life. There have been articles in a feminist-legal-theory vein supporting efforts similar to those in Indianapolis, ${ }^{5}$ and there has been work using a feminist perspective to argue against such ordinances. ${ }^{6}$ There has been scholarship employing First Amendment theory to criticize the MacKinnon-Dworkin approach. ${ }^{7}$ There

* Professor of Law, University of Oklahoma. A.B., Franklin \& Marshall College; M.S., M.A., Ph.D., University of Miami; J.D., University of Michigan. The author wishes to thank Fred Schauer and Greg Sisk for their willingness to read and comment on earlier drafts of this article.

1. For a discussion of the ordinance, see infra notes $18-53$ and accompanying text. In addition to distribution, the ordinance prohibited coercing anyone into a pornographic performance and forcing pornography on a person. A cause of action for injuries resulting from pornography was also included.

2. See American Booksellers Ass'n v. Hudnut, 598 F. Supp. 1316 (S.D. Ind. 1984).

3. 771 F.2d 323 (7th Cir. 1985), aff'd, 475 U.S. 1001 (1986).

4. 475 U.S. 1001 (1986).

5. See, e.g., CATHARINE A. MACKInNON, ONLY Words (1993); Catharine A. MacKinnon, Pornography as Defamation and Discrimination, 71 B.U. L. REV. 793 (1991); Patricia G. Barnes, A Pragmatic Compromise in the Pornography Debate, 1 TEMP. PoL. \& CIV. RTS. L. REV. 117 (1992). See also infra notes 28-36 and accompanying text.

6. See infra notes 37-41 and accompanying text.

7. See, e.g., C. Edwin Baker, Of Course, More than Words, 61 U. CHI. L. REv. 1181 (1994) (reviewing CATHARINE A. MACKInNON, ONLY WORDS (1993)); Dan Greenberg \& Thomas H. Tobiason, The New Legal Puritanism of Catharine MacKinnon, 54 OHIO ST. L.J. 1375 (1993); Amold H. Loewy, Obscenity, Pornography, and First Amendment Theory, 2 
has also been an effort to show that other constitutional provisions justify the infringement of free speech involved in the ordinance. ${ }^{8}$ There has even been scholarship that uses First Amendment theory, although different from the approach to be taken here, to support ordinances similar to those in Indianapolis. ${ }^{9}$

Canada also sought to limit the distribution of pornographic material similar to that addressed in Indianapolis, but Canada's attempt met with a different fate in the Canadian courts. The Canadian act addressed material that unduly exploited sex or combined sex with violence, crime, horror or cruelty. That statute was challenged in The Queen $v$. Butler, ${ }^{10}$ where its reception was more positive than that which faced the Indianapolis ordinance. The Supreme Court of Canada held that the statute passed the tests of the Canadian Charter of Rights and Freedoms. Butler has engendered some scholarly notice as well. ${ }^{11}$

While analyses under the United States Constitution and the Canadian Charter of Rights and Freedoms would proceed along different paths and might well lead to different conclusions, both inquiries may rest on the nature of obscenity. ${ }^{12}$ This article will suggest an understanding of obscenity which will reveal that the Canadian approach has a superior historical foundation. With regard to the Indianapolis ordinance, at least some of its aspects (or a similar ordinance addressing some of the goals of the original ordinance and employing different language) ought to be constitutional. The

WM. \& MARY BILL RTS. J. 471 (1993). See also infra notes $42-53$ and accompanying text.

8. Feminist theory, such as that cited in supra note 5 , argues that pornography, by devaluing women, denies women a voice in contravention of the ideals of the Equal Protection Clause. This approach has also been taken with respect to speech that affects the ability of minorities to contribute to the political debate. See generally MARI MATSUDA ET AL., WORDS That Wound: Crmical RaCe Theory, Assaultive SPEech, AND the First AMENDMENT (Robert W. Gordon \& Margaret Jane Radin eds., 1993).

9. See, e.g., Cass R. Sunstein, Pornography and the First Amendment, 1986 DUKE L.J. 589 (1986) (arguing that pornography is low-value speech and can be regulated consistent with the First Amendment); Alon Harel, Bigotry, Pornography, and the First Amendment: $A$ Theory of Unprotected Speech, 65 S. CAL. L. REV. 1887 (1992) (arguing that "abhorrent" speech is not political and is not protected because the influence it exerts is "illegitimate").

10. [1992] 89 D.L.R. 4th 449 (Can.).

11. See, e.g., Amy Adler, What's Left?: Hate Speech, Pornography, and the Problem for Artistic Expression, 84 CALIF. L. REV. 1499, 1510-11, 1530 (1996); Jeffrey Sherman, Love Speech: The Social Utility of Pornography, 47 STAN. L. REV. 661,690 (1995); Michael K. Curtis, "Free Speech" and its Discontents: The Rebellion Against General Propositions and the Danger of Discretion, 31 W AKE FOREST L. REV. 419, 441-43 (1996).

12. The Canadian statute, by its terms, addressed obscene materials as defined in the statute. See infra notes 54-56 and accompanying text. The Indianapolis ordinance addressed pomographic material, which it defined in a manner differing from the United States Supreme Court's definition of obscenity. See infra notes 18-25 and accompanying text. It is the major thesis of this article, however, that the material at issue in Hudnut comes within the scope of the concept of obscenity. 
"ought" used is not used in the sense some feminists might use it in arguing that the Constitution should not be allowed to stand in the way of equality. ${ }^{13}$ Instead, the concept of obscenity, properly understood, should provide partial support for the feminists' efforts.

This article begins by examining the Indianapolis ordinance and the legal reaction to it. ${ }^{14}$ The Canadian statute is then similarly treated. ${ }^{15}$ Attention then turns to a discussion on the concept of obscenity and its legal definition. This article argues that the hallmark distinguishing obscene pornography from nonobscene pornography is the degrading nature of the images involved, particularly as they speak to the position of humanity between the divine and the animal world. ${ }^{16}$ The history of pornography and of its legal treatment are best explained by changes in the views of humanity's position rather than by the common suggestion that the changes result from technological growth, the invention of the printing press or the invention of the paperback book. With this reexamined definition of obscenity, the statute and ordinance also may be reexamined, and suggestions are made as to how an Indianapolis-like ordinance could be written to pass constitutional muster. ${ }^{17}$

\section{THE INDIANAPOLIS ORDINANCE AND HUDNUT}

The Indianapolis ordinance at issue in Hudnut defined "pornography" as:

the graphic sexually explicit subordination of women, whether in pictures or in words, that also includes one or more of the following:

(1) Women are presented as sexual objects who enjoy pain or humiliation; or

(2) Women are presented as sexual objects who experience sexual pleasure in being raped; or

(3) Women are presented as sexual objects tied up or cut up or mutilated or bruised or physically hurt, or as dismembered or truncated or fragmented or severed into body parts; or

(4) Women are presented as being penetrated by objects or animals; or

(5) Women are presented in scenarios of degradation, injury, abasement, torture, shown as filthy or inferior, bleeding, bruised, or hurt in a context that makes these conditions

13. See sources cited supra note 5.

14. See infra notes $18-53$ and accompanying text.

15. See infra notes 53-82 and accompanying text.

16. See infra notes 83-254 and accompanying text.

17. See infra notes $255-260$ and accompanying text. 
sexual; or

(6) Women are presented as sexual objects for domination, conquest, violation, exploitation, possession, or use, or through postures or positions of servility or submission or display. ${ }^{18}$

While the original ordinance provided a definition of "sexually explicit" as "actual or simulated intercourse or the uncovered exhibition of the genitals, buttocks or anus," 19 a later amendment left the ordinance with no definition of that phrase. ${ }^{20}$

There were a variety of prohibitions contained in the ordinance. The ordinance declared it illegal to traffic in pornography, to coerce others to perform in pornographic works, or to force pornography on anyone. ${ }^{21}$ The ordinance also prohibited assault on or injury to any person "in a way that is directly caused by specific pornography."22 Furthermore, "anyone injured by someone who . . . saw or read pornography" was provided a cause of action against the producer or distributor of that pornographic work..$^{23}$ Any woman aggrieved by trafficking in pornography was granted the right to file a complaint with the Indianapolis equal opportunity office "as a woman acting against the subordination of women." 24 Men who could "prove injury in the same way that a woman is injured" could do the same. ${ }^{25}$

It is clear that the ordinance went beyond addressing only obscene material. Under the test adopted in Miller $v$. California, ${ }^{26}$ a finding of obscenity depends on

(a) whether 'the average person, applying contemporary community standards' would find that the work, taken as a whole, appeals to the prurient interest ... ; (b) whether the work depicts or describes, in a patently offensive way, sexual conduct specifically defined by the applicable state law; and (c) whether the work, taken as a whole, lacks serious literary, artistic, political, or scientific value. ${ }^{27}$

18. INDIANAPOLIS, IND., CODE § 16-3(q) (1984).

19. American Booksellers Ass'n v. Hudnut, 771 F.2d 323, 324 (7th Cir. 1985), aff'd, 475 U.S. 1001 (1986).

20. See id.

21. See id. at 325 .

22. INDIANAPOLIS, IND., CODE § 16-3(g)(7) (1984).

23. Hudnut, 771 F.2d at 325.

24. INDIANAPOLIS, IND., CODE $§ 16-17$ (b) (1984).

25. Id.

26. 413 U.S. 15 (1973), reh'g denied, 414 U.S. 881 (1973).

27. Id. at 24 (quoting Roth v. United States, 304 U.S. 476, 489 (1957)) (citations omitted). 
The ordinance made no reference to prurient interests or community standards and addressed particular depictions rather than judging the work as a whole and protecting it if it had serious value. These factors appear not to have been simply overlooked. Supporters of the ordinance maintained that "pornography influences attitudes, and the statute is a way to alter the socialization of men and women rather than to vindicate community standards of offensiveness." 28 Catharine MacKinnon, one of the principal drafters of the ordinance, also argued "if a woman is subjected, why should it matter that the work has other value?"29

The feminist attack on pornography, at least as presented in the ordinance, is not directed at the repression of sexual knowledge or sexual freedom. The concern is over the effect certain depictions of sexuality may have on the lives of women. ${ }^{30}$ This focus leads to a delineation of the sort of material under attack which differs from that in Miller. Feminists are concerned with materials that cause harm to women, and their definition of pornography singles out material that makes the domination or submission of women erotic or degrades women by treating them as objects to be sexually exploited. Thus, under this feminist view, sexual explicitness is not central; a portrayal maintaining the dignity of all the participants is not pornographic, even if it is sexually explicit. ${ }^{31}$ For the feminist, it is not sex or the human body that offends; it is the degrading depiction of women.

The concern over pornography is not simply moral or aesthetic. Pornography is seen as causing harm to women. ${ }^{32}$ It is both a symptom of sexual inequality and patriarchy, and it is a cause of both. This effect is seen as so pervasive that it defines reality. "[Pornography] institutionalizes the sexuality of male supremacy, fusing the erotization of dominance and submission with the social construction of male and female . . . . Men treat women as who they see women as being. Pornography constructs who that is." 33

28. Hudnut, 771 F.2d at 325.

29. Catharine A. MacKinnon, Pornography, Civil Rights, and Speech, 20 HARv. C.R.-C.L. L. REv. 1, 21 (1985).

30. See Caryn Jacobs, Patterns of Violence: A Feminist Perspective on the Regulation of Pornography, 7 HARV. WoMEN's L.J. 5, 23 (1984). See also Andrea Dworkin, Against the Male Flood: Censorship, Pornography, and Equality, 8 HARV. WOMEN's L.J. 1,9 (1985) ("The insult pornography offers, invariably, to sex is accomplished in the active subordination of women: the creation of a sexual dynamic in which the putting down of women, the suppression of women, and ultimately the brutalization of women, is what sex is taken to be." (emphasis in original)).

31. See Jacobs, supra note 30 , at 24.

32. See Richard Delgado \& Jean Stefancic, Pornography and Harm to Women: “No Empirical Evidence?," 53 OHIO ST. L.J. 1037, 1045 (1992).

33. Hudnut, 771 F.2d at 328 n.1 (quoting Catharine A. MacKinnon, Pornography, Civil Rights, and Speech, 20 HARV. C.R.-C.L. L. REV. 1, 17 (1985)). 
Given this view of pornography's effects on the construction of reality, feminists do not see pornography as solely a moral issue. Rather, feminists see it as a civil rights issue affecting all aspects of women's lives by perpetuating patterns of discrimination. Pornography is seen as trivializing the contributions of women in the workplace and encouraging sexual harassment. ${ }^{34}$ The asserted effects go beyond the workplace and affect all aspects of women's lives, suggesting "that women are a lower form of human life defined by their availability for sexual use."35 Professor MacKinnon concludes that pornography decreases inhibitions on, and increases acceptance of, aggression against women, reduces the desire of both males and females to have female children, and fosters a belief in male domination. ${ }^{36}$

Not all feminists share this view of pornography. Professor Nadine Strossen has offered counter-arguments to those presented by MacKinnon and others. ${ }^{37}$ Her arguments are not solely based on First Amendment grounds, but also include arguments she sees as grounded in the principles and concerns of feminism. ${ }^{38}$ It is clear that she considers herself a feminist, and she objects to what she calls the "widespread misperception that if you are a feminist - or a woman - you must view 'pornography' as misogynistic and 'detrimental' to women. And you must favor censoring it. $" 39$

Strossen is not alone in feminist opposition to the MacKinnon-Dworkin thesis. The Feminists Anti-Censorship Taskforce and Feminists for Free Expression have both opposed legislative efforts to enact the sort of censorship advocated in feminist attacks on pornography. ${ }^{40}$ Strossen's feminist arguments against censoring pornography include concerns that censorship would affect works that are important to women, particularly to feminists and lesbians and that it would perpetuate stereotypes of women as victims for whom sex is necessarily bad, harming women's efforts to develop their sexuality and strengthening patriarchy. ${ }^{41}$ Certainly, MacKinnon has not missed these arguments, but she comes to a different conclusion because of what she sees as the overwhelmingly negative effect of pornography on women.

34. See Jacobs, supra note 30 , at 19.

35. MacKinnon, supra note 5, at 802.

36. See id. at 800 .

37. See generally Nadine Strossen, Defending PoRNography: Free SPEech, SEX, AND THE FIGHT FOR WOMEN's RIGHTS (1995); Nadine Strossen, A Feminist Critique of "The" Feminist Critique of Pornography, 79 VA. L. REv. 1099 (1993).

38. See Strossen, supra note 37, at 1103.

39. Id. at 1107 (footnotes omitted).

40. See id. at 1109-10.

41. See id. at 1111-12. 
The purpose of this article is not to join the feminist debate over the impact of pornography on the lives of women. Rather, the focus is on the First Amendment and its impact on legislation such as that at issue in Hudnut. A good starting point for that issue is the opinion of the Hudnut court.

The Seventh Circuit found fault with the Indianapolis ordinance in that the ordinance discriminated on the basis of the content of speech.

Speech treating women in the approved way - in sexual encounters 'premised on equality' . . . is lawful no matter how sexually explicit. Speech treating women in the disapproved way - as submissive in matters sexual or as enjoying humiliation is unlawful no matter how significant the literary, artistic, or political qualities of the work taken as a whole..$^{42}$

The unconstitutional flaw the court saw was that of viewpoint discrimination. As the court noted, just as the First Amendment protects speech by Nazis and the Ku Klux Klan, it protects the use of nonobscene sexual images in expressing a view contrary to that of feminists. ${ }^{43}$

The ordinance was seen as being other than content neutral. It defined the banned sexually explicit materials based on the perspective presented in the materials. If the material depicted women as enjoying pain, humiliation, or rape, or simply in a position of servility or submission, it was pornographic and restricted. On the other hand, material portraying women as equals was unrestricted, regardless of the material's graphic sexual content. ${ }^{44}$ As the court said: "This is thought control. It establishes an 'approved' view of women, of how they may react to sexual encounters, of how the sexes may relate to each other. Those who espouse the approved view may use sexual images; those who do not, may not." 45

With regard to the argument that pornography changes people and contributes to the subordination of women, the court said:

[T]his simply demonstrates the power of pornography as speech. All of these unhappy effects depend on mental intermediation. Pornography affects how people see the world, their fellows, and social relations. If pornography is what pornography does, so is other speech. Hitler's orations affected how some Germans saw

42. See American Booksellers Ass'n v. Hudnut, 771 F.2d 323, 325 (7th Cir. 1985) aff'd, 475 U.S. 1001 (1986) (citation omitted).

43. See id. at 328.

44. If the material was sufficiently graphic and offensive and otherwise met the definition of "obscene," it could, of course, be addressed under a separate obscenity statute.

45. Hudnut, 771 F.2d at 328. 
Jews. Communism is a world view, not simply a Manifesto by Marx and Engels or a set of speeches. ${ }^{46}$

The court also addressed the argument that, because pornography is "unanswerable," the "marketplace of ideas" metaphor does not apply, and First Amendment protection is lost. ${ }^{47}$ The court responded that the likelihood of truth winning out is not a necessary condition for First Amendment protection. In fact,

[a] power to limit speech on the ground that truth has not yet prevailed and is not likely to prevail implies the power to declare truth. At some point the government must be able to say (as Indianapolis has said): "We know what the truth is, yet a free exchange of speech has not driven out falsity, so that we must now prohibit falsity." 48

The state cannot have this power. According to the court, the state must not be allowed to determine the truth and suppress the expression of those who disagree, even for speech that is "effectively unanswerable."49

The last argument the court addressed was that pornography is "lowvalue" speech and thus is sufficiently similar to obscenity to be prohibited. While recognizing a distinction between the political speech at the core of the First Amendment and speech of lesser value, the court noted that no cases have sustained viewpoint discrimination. ${ }^{50}$ According to Hudnut, the topic determines the position of speech as core speech or as removed from the core; the position expressed on the topic is irrelevant. ${ }^{51}$ Even more telling, the court noted that pornography, as defined by the ordinance, is not lowvalue speech. ${ }^{52}$ As such, the city's motivation in restricting pornography was the influence such material has on political and social relations. The court saw that influence as indicative of core speech rather than low-value

46. Id. at 329.

47. See id. at 330.

48: Id. at $330-31$.

49. Id. at 331. The court offered several United States Supreme Court opinions in support of this proposition. It took the Court's determination in Buckley v. Valeo, 424 U.S. 1 (1976), making it unconstitutional to limit campaign expenditures, even though the rules were designed to make it easier for candidates to answer each other's speech, as such a case. See Hudnut, 771 F.2d at 331. Similarly, the court noted that Mills v. Alabama, 384 U.S. 214 (1966), held unconstitutional a statute prohibiting election day editorials, even though the statute was designed to prevent speech that was printed so late as to be unanswerable. See Hudnut, 771 F.2d at 331.

50. See Hudnut, 771 F.2d at 331.

51. See id. at 331-32.

52. See id. 
speech. ${ }^{53}$

The court was clear in its belief that the ordinance violated the First Amendment and seemed unconvinced that feminist concerns could override the protections afforded by that amendment. It may be, however, that at least some of the ordinance can be saved. To understand which portions may be constitutional, it is necessary to examine the obscenity exception. The ordinance can survive to the degree that it fits within that exception. However, before delving into the obscenity exception, the Canadian statute and its legal reception will be discussed.

\section{THE CANAdian STATUTE AND BUTLER}

The Canadian statute at issue in The Queen v. Butler ${ }^{54}$ provides: "Every one commits an offence who, (a) makes, prints, publishes, distributes, circulates, or has in his possession for the purpose of publication, distribution or circulation any obscene written matter, picture, model, phonograph record or other thing whatever ...."5s The provision defines "obscene" as "any publication a dominant characteristic of which is the undue exploitation of sex, or of sex and any one or more of the following subjects, namely, crime, horror, cruelty and violence." 56 As the Butler Court explained the statutory provisions, the determination of whether the exploitation of sex is undue turns on the application of the "community standard of tolerance" test, a test "concerned not with what Canadians would not tolerate being exposed to themselves, but what they would not tolerate other Canadians being exposed to." 57 The Court pointed to a growing recognition that the exploitation of sex in a manner that degrades or dehumanizes will fail the community standards test, by "plac[ing] women (and sometimes men) in positions of subordination, servile submission or humiliation . . . [a]gainst the principles of equality and dignity of all human beings." 58

An additional aspect of the Canadian test for obscenity is the "internal

53. The court also briefly considered the possibility that the materials affected by the ordinance could be considered group libel. While Beauharnais allowed proscription of group libel, the court concluded that later cases had so weakened Beauharmais that it could no longer be considered authoritative. See Hudnut, 771 F.2d at 332 n.3. The court also said that, even if Beauharnais is still authoritative, it was not clear that the materials addressed by the ordinance constituted group libel. See id. "Work must be an insult or slur for its own sake to come within the ambit of Beauharnais, and a work need not be scurrilous at all to be 'pornography' under the ordinance." Id. (emphasis added).

54. [1992] 89 D.L.R. 4th 449.

55. Criminal Code, R.S.C., ch. C-46, $\S 163(1)(1985)$ (Can.).

56. Id. $\S 163(8)$.

57. Butler, 89 D.L.R. 4th at 465-66 (emphasis in original).

58. Id. at 466. 
necessities" test, also known as the "artistic defence." That test asks "whether the exploitation of sex has a justifiable role in advancing the plot or the theme, and in considering the work as a whole, does not merely represent 'dirt for dirt's sake' but has a legitimate role when measured by the internal necessities of the work itself." 59 When material passes the "internal necessities" defense, the question becomes one of whether the sexually explicit material, in context, would be tolerated by the community, with any doubt resolved in favor of the freedom of expression. ${ }^{60}$

The Court saw the measure of community tolerance as based on an assessment of the harm that would flow from the exposure of the community to the materials at issue, the harm being the predisposing of people to act in an antisocial manner. With regard to the application of the test to what it saw as the three varieties of pornographic material, the Court concluded:

[T] he portrayal of sex coupled with violence will almost always constitute the undue exploitation of sex. Explicit sex which is degrading or dehumanizing may be undue if the risk of harm is substantial. Finally, explicit sex that is not violent and neither degrading nor dehumanizing is generally tolerated in our society and will not qualify as the undue exploitation of sex unless it employs children in its production. ${ }^{61}$

It is tempting to explain the ability of Canadian law to address degradation and dehumanization in a way United States law cannot on the existence of the First Amendment to the United States Constitution. However, the Canadian Charter of Rights and Freedoms contains a provision very similar to the First Amendment. Section 2 of the Charter provides: "Everyone has the following fundamental freedoms: (a) freedom of conscience and religion; (b) freedom of thought, belief, opinion and expression, including freedom of the press and other media of communication; (c) freedom of peaceful assembly; and (d) freedom of association." 62 Indeed, the Butler Court addressed the issue raised by section 2 and concluded that the purpose and effect of the obscenity statute was the limiting of certain expression based on its content, thereby infringing section 2(b). ${ }^{63}$

As with United States constitutional law, the holding that a protection

59. Id. at 469 .

60. See id. at 471.

61. Id. The opinion of Justice Gonthier, joined by Justice L'Heureux-Dubé, while agreeing in large part with the majority opinion of Justice Sopinka, questioned the protected status of material in the third category. See id. at 489-99.

62. Constitution Act, 1982, Canadian Charter of Rights and Freedoms $\S 2$, sched. B, 1980-1983 S.C. 5 (Can.).

63. See Butler, 89 D.L.R. 4th at 473. 
was infringed demanded justification. The Canadian Charter of Rights and Freedoms provides the test for justifying such infringements in its first section. "The Canadian Charter of Rights and Freedoms guarantees the rights and freedoms set out in it subject only to such reasonable limits prescribed by law as can be demonstrably justified in a free and democratic society." 64

While the language of section 1 may seem less stringent than the strict scrutiny of United States constitutional law, the test, as applied by the Butler Court, is actually quite similar. The Court first had to identify a "pressing and substantiai objective." 65 The Court did not rule out the power of Parliament "to legislate on the basis of some fundamental conception of morality for the purposes of safeguarding the values which are integral to a free and democratic society." ${ }^{\circ 6}$ Nonetheless, the Court instead identified the overriding objective of the obscenity statute as the avoidance of harm. The Court described the harm as follows:

The clear and unquestionable danger of this type of material is that it reinforces some unhealthy tendencies in Canadian society. The effect of this type of material is to reinforce male-female stereotypes to the detriment of both sexes. It attempts to make degradation, humiliation, victimization, and violence in human relationships appear normal and acceptable. A society which holds that egalitarianism, non-violence, consensualism, and mutuality are basic to any human interaction, whether sexual or other, is clearly justified in controlling and prohibiting any medium of depiction, description or advocacy which violates these principles. ${ }^{67}$

The Court then went on to hold that the objective of preventing the evils described was pressing and substantial. ${ }^{68}$

The second part of the Canadian test is a "proportionality" requirement, which is similar to the narrow tailoring requirement of United States constitutional law. The proportionality requirement has three factors: “(1) the existence of a rational connection between the impugned measures

64. Constitution Act, 1982, Canadian Charter of Rights and Freedoms $\S 1$, sched. B, 1980-1983 S.C. 5 (Can.).

65. Butler, 89 D.L.R. 4th at 475 . Actually, the court first dismissed a challenge based on vagueness. The court said that terms such as "undue," while they may not be subject to precise definition, are inevitably a part of the law, and prior interpretations of section 163 of the Criminal Code provide an "intelligible standard." $1 d$. at 475.

66. Id. at 476.

67. Id. at 477 (quoting STANDING COMM. ON JUSTICE AND AFFAIRS, REPORT ON PORNOGRAPHY 18:4 (1978)).

68. See id. at $478-80$. 
and the objective; (2) minimal impairment of the right or freedom[;] and (3) a proper balance between the effects of the limiting measures and the legislative objective." ${ }^{99}$

With regard to the rationality of the measure, the Court concluded that it was rational to believe that exposure to the images addressed by the statute could cause changes in attitudes and beliefs that would be harmful to society. ${ }^{70}$ The Court admitted that it was difficult, if not impossible, to establish a direct causal link but believed that "Parliament was entitled to have a 'reasoned apprehension of harm' resulting from the desensitization of individuals exposed to materials which depict violence, cruelty, and dehumanization in sexual relations." 71

Minimal impairment, the second factor, does not require a perfect fit between the measure and the problem addressed, but the measure must be "appropriately tailored in the context of the infringed right."72 The Court pointed to several factors that established minimal impairment. ${ }^{73}$ First, sexually explicit material that is not violent or dehumanizing is not restricted. ${ }^{74}$ Second, material with scientific, artistic or literary value remains protected. ${ }^{75}$ Third, Parliament's earlier unsuccessful efforts to develop a more specific definition indicate that the statutory definition is as precise as can be offered. ${ }^{76}$ And fourth, the statute did not reach the private possession and use of obscene materials but addressed only public exhibition and distribution. ${ }^{n}$ The Court also concluded that any suggested alternatives would be less effective. ${ }^{78}$

Turning finally to the balancing aspect of the proportionality test, the Court stated the test as "whether the effects of the law so severely trench on a protected right that the legislative objective is outweighed by the infringement." 79 The material affected was seen as "far from the core of the guarantee of freedom of expression ... [and] appeal[ing] only to the most base aspect of individual fulfilment." 80 On the other hand, the statute's objective, the avoidance of harm and fostering of respect for all members of society, was seen to be of fundamental importance.

If Butler had been an opinion by a United States court, it would

69. Id. at 481 .

70. See id. at 483.

71. Id. at 484 .

72. Id. at 485.

73. See id. at 485-87.

74. See id. at 485.

75. See id.

76. See id.

77. See id. at 486.

78. See id.

79. Id. at 487-88.

80. Id. at 488. 
probably be interpreted as holding that restricting violent or dehumanizing pornography passes strict scrutiny and can be justified in spite of the infringement of freedom of expression. That is the conclusion which Hudnut refused to reach; as such, Butler conflicts with Hudnut. However, there is also language in Butler indicating that the material at issue merits less protection than other expression. The values supporting the Canadian guarantee of freedom of expression were said to "relate to the search for truth, participation in the political process, and individual self-fulfilment." Of those values, only individual self-fulfilment was implicated, and even then the Court said only in one of its most base aspects. The material at issue was seen as even having less value than "good pornography," which may question traditional ideas of sexuality or may celebrate human sexuality. In the Court's view, the material at issue "does not stand on equal footing with other kinds of expression which directly engage the 'core' of the freedom of expression values." 82

The position that violent, degrading, or dehumanizing pornography merits less protection than other expression would seem more analogous to a claim that such material comes within an exception to the freedom of expression. If that approach is to be carried over to United States law, the best fit would be a theory that violence, degradation, or dehumanization are factors that can serve to place sexually explicit material within that class of pornography considered obscene and unprotected by the First Amendment. Establishing such a claim will require an examination of the obscenity exception and the variety of materials that have traditionally been considered obscene. It is to that examination which this article now turns.

\section{REEXAMINING THE OBSCENITY EXCEPTION TO THE UNITED STATES CONSTITUTION}

As established in Roth $v$. United States, ${ }^{83}$ material is not protected by the First Amendment if the material is obscene. Miller $v$. California ${ }^{84}$ provides a three-factor test for measuring the limits of that exception. The third prong, which asks whether the work has serious value when taken as a whole, provides the greatest difficulty for the Indianapolis ordinance. Despite Professor MacKinnon's assertion that it should not matter that the material has serious value if women are harmed, it does matter for purposes of First Amendment law. Clearly, to use the obscenity exception to justify the ordinance, the ordinance would have to be modified to provide protection 
for material with "serious literary, artistic, political, or scientific value." 85

The second prong, "whether the work depicts or describes, in a patently offensive way, sexual conduct specifically defined by the applicable state law, " can be met through another modification. While the intent of the ordinance was to focus on the extra-erotic aspects of the depiction, the ordinance could be modified to specify the types of sexual conduct addressed. This modification may no longer include some erotic material that degrades women, but it is a trade-off which appears necessary. MacKinnon and Dworkin appeared willing to allow such a trade-off in hope of constitutionality. Their ordinance addressed only erotic material rather than all material presenting negative images of women. Without this concession, it would be difficult to attach the pornography label to the targeted material or to tie the ordinance, however loosely, to a recognized First Amendment exception. Requiring that the second prong of the Miller test be met would seem a minor additional concession to avoid vagueness.

The real obstacle appears to be in the first prong's requirement that under community standards the material, taken as a whole, appeal to the prurient interest. However, if "prurient" were seen to have a meaning that matched the concerns behind the ordinance, the ordinance, again at least in part, might be saved.

\section{A. Prurience and Degradation}

It was the Roth Court which introduced the "appeal-to-the-prurientinterest" requirement into the constitutional test of obscenity. The Court also defined material appealing to the prurient interest as "material having a tendency to excite lustful thoughts" ${ }^{87}$ and defined prurient as "[i]tching; longing; uneasy with desire or longing; of persons, having itching, morbid, or lascivious longings; of desire, curiosity, or propensity, lewd." 88 The resulting formulation, the Court said, did not differ significantly from the Model Penal Code approach that material is obscene "if, considered as a whole, its predominant appeal is to the prurient interest, i.e., a shameful or morbid interest in nudity, sex, or excretion, and if it goes substantially beyond customary limits of candor in description or representation of such matters." 89 While the definition includes the propensity to excite lustful thoughts, it appears that more is required. All erotic material has a

85. Id.

86. Id.

87. Roth, 354 U.S. at 487 n. 20 .

88. Id. (quoting WeBSTER's NeW INTERNATIONAL DictionaRY (unabridged $2 \mathrm{~d}$ ed. 1949)).

89. Id. (quoting MODEL PENAL CODE § 207.10(2) (Tentative Draft No. 6, 1957)) (emphasis added). 
propensity to excite lustful thoughts, but not all erotic material is obscene. What is additionally required is that the interest have a shameful or morbid quality to it.

This combination of attraction and shame may seem puzzling. Professor Cass Sunstein suggests that the dual reactions require a strange psychological state. ${ }^{90}$ The combination may not be as psychologically odd as Sunstein indicates. However, in order to understand this combination, it is necessary to examine the nature of sexual response to visual stimuli.

According to psychology's James-Lange theory, ${ }^{91}$ stimuli that produce emotions do so without the initial input of the more evolved portions of the brain. ${ }^{92}$ Visual images that lead to sexual stimulation do involve the optic regions of the brain in processing the optic nerve input. The route to stimulation, however, is through the limbic regions, particularly the amygdala. In any such emotional reaction, the limbic system sets off a series of physiological responses, including muscular, nervous system and hormonal reactions. The responses occur at a level below the conscious. ${ }^{93}$ The individual so stimulated recognizes the stimulation through feedback from the systems engaged in the physiological responses. ${ }^{94}$ The brain recognizes an increased heart rate and a surge in sex hormones. ${ }^{95}$ The James-Lange theory holds that it is the brain's experience of the physiological responses that constitutes our feelings of emotions. ${ }^{96}$ The experience at the conscious level is secondary and occurs only as the chain of events set off by the stimulation passes through the brain for the second time. ${ }^{97}$

The James-Lange theory explains how an individual can be both excited and feel shame as a result of the excitement. The excitement is the result of processes that are below the level of consciousness. The higher order brain recognizes the excitement and is ashamed of it. What remains, however, is the question of why the excitement should be shameful. It would seem that a psychologically healthy person would not consider all feelings of sexual excitement morbid or shameful. The fact that the feelings resulted from visual stimulation alone would not seem to add any shame. What, then, is it that makes the excitement we experience from some images shameful, while sexual excitement brought on by other stimuli feels healthy (1993).

90. See generally CASS R. SUNSTEIN, DemocraCy AND the PRoblem OF FreE SPEECH

91. See, e.g., Neil R. Carlson, Physiology of Behavior 350-51 (5th ed. 1994).

92. See id. at 350 .

93. See id.

94. See id.

95. See id.

96. See id.

97. See id. 


\section{and normal?}

That question is, of course, one of the major difficulties in applying the obscenity test. While there may be questions over whether a work has serious value and statutory prohibitions may be vague, the issue of what sort of images appeal to the prurient interest has been the most vexing. Society may not have progressed beyond Justice Stewart's test of "I know it when I see it."98 While Justice Stewart was speaking of the Roth test requirement that the material at issue go "substantially beyond customary limits of candor," 99 the issue of shamefulness of sexual excitement has received no better definition.

Perhaps the best explanation of this requirement of shame is that offered in the extra-legal analysis of the concept of obscenity provided by Professor Harry Clor. He asserts that obscenity consists of "a degradation of the human dimensions of life to a sub-human or merely physical level."100 For Clor, "[o]bscene literature may be defined as that literature which presents, graphically and in detail, a degrading picture of human life and invites the reader or viewer, not to contemplate that picture, but to wallow in it. $" 101$

Clor's analysis explains the distinction between the depiction of romance and the depiction of sex. It is the depiction of the human spirit that distinguishes a romantic film, even a romantic film depicting explicit sex, from the explicit sex that might make another film obscene. In the sexually obscene film, the participants are reduced to the subhuman, merely physical level. It is not the sexual act, but rather the focus solely on the physical aspects of that act to the exclusion of the human spirit that degrades the individuals depicted and makes it obscene.

This idea of degradation as central to the extra-legal concept of obscenity also finds an interesting basis in the history of obscenity law. When the Roth Court looked for historical support for the obscenity

98. Jacobellis v. Ohio, 378 U.S. 184, 197 (1964) (Stewart, J., concurring).

99. Roth, 354 U.S. at 487 n.20 (quoting MODEL PENAL CODE $\$ 207.10(2)$ (Tentative Draft 1957)). For an explanation of this difficulty see, 2 JOEL FEINBERG, THE MORAL LIMITS OF THE CRIMINAL LAW: OFFENSE TO OTHERS 97-126 (1984). He finds the non-legal concept of obscenity to extend far beyond sex to reach all things sufficiently offensive as to produce disgust, shock or repugnance, things that "send shudders up our spines and set our teeth on edge." Id. at 112 . He also suggests a plausible psychological origin for such a reaction in the parental implantation in infants of what he calls the "Yuk reaction." Id. at 112-15. Infants are very willing to place anything that fits into their mouths. When a parent reacts with "No!," "Dirty!," "Nasty!" or "Yuk!," the infant learns that this is unacceptable behavior in a sense that differs from the morally or aesthetically unacceptable. Id. at 113. This suggested early implantation of the concept explains the visceral nature of ascriptions of obscenity.

100. HaRRY M. CloR, OBSCENITY AND PUblic MORALITY: CENSORSHIP IN A LIBERAL SOCIETY 225 (1969).

101. Id. at 234 . 
exception, it turned to statutes and cases demonstrating that "[a]t the time of the adoption of the First Amendment, obscenity law was not as fully developed as libel law, but there is sufficiently contemporaneous evidence to show that obscenity, too, was outside the protection intended for speech and press."102 The earliest of the cases cited, dating from 1808, is Knowles v. State. ${ }^{103}$ Knowles was convicted of violating Connecticut's restrictions on plays and public performances by displaying a "horrid and unnatural monster." 104 The description offered of the monster in question indicates that the concept of obscenity in the Bill of Rights era went beyond sex. The description of the monster was as follows:

And the head of said monster, represented by said picture, resembles that of an African, but the features of the face are indistinct: there are apertures for eyes, but no eyes; his chin projects considerably, and the ears are placed unnaturally back, on or near the neck; its fore legs, by said picture, are here represented to lie on its breast, nearly in the manner of human arms; its skin is smooth, without hair, and of a dark, tawny, or copper color. ${ }^{105}$

The presentation of the "monster" was said to be "highly indecent" and the showing contrary to the State's statutory law. ${ }^{106}$

Knowles' conviction was affirmed at the first appellate stage but was reversed by the Connecticut Supreme Court, with the court holding that his exhibition was not within the scope of the statute. ${ }^{107}$ The only cited statute prohibited "any games, tricks, plays, shows, tumbling, rope-dancing, puppet-shows, or feats of uncommon dexterity or agility of body." ${ }^{108}$ Only the prohibition against shows could apply to Knowles, and "shows" had no technical meaning and could not be extended to the simple exhibition of art, natural curiosities or museum collections. ${ }^{109}$ When the court turned to a consideration of the common law, it did accept the proposition that "[e]very public show and exhibition, which outrages decency, shocks humanity, or is contrary to good morals, is punishable at common law." 110 However, even under the common law, the conviction could not stand, because the information did not "particularly state the circumstances in which the

102. Roth, 354 U.S. at 483.

103. 3 Day 103 (Conn. 1808).

104. Id. (emphasis added).

105. Id. (emphasis added).

106. Id. at 104.

107. See id. at 107.

108. Id.

109. See id.

110. ld. at $107-08$. 
indecency, barbarity or immorality, consists." "11

What should be clear from Knowles is that the concept of obscenity in that era was not limited to sex. The display at issue was not sexual but was one in which a human being was treated as, or degraded to, something less than human. The discussion returns to the tie between obscenity and degradation after examining the relationship between obscenity and religion and the development of sexual obscenity law. It will be suggested that degradation, religion, and sex tie together to provide an explanation for the development of sexual obscenity law.

\section{B. Religion and Obscenity}

An examination of the history of obscenity further strengthens the tie to degradation. This history also has an interesting focus on religion. In fact, it is generally agreed that the early focus on obscenity law was the protection of religion. Professor Schauer notes that "the origins of obscenity regulation are religious. In ancient times, sexual explicitness in the drama or in written works was fully tolerated ... [; h]owever, blasphemy and heresy were both strongly condemned." 112 Schauer cites Athenian prosecutions for blasphemy and the execution of Socrates in the Greek era as proof of this contention. ${ }^{113}$ He notes the religiously motivated destruction of the Analects of Confucius in ancient China and compares the "virtually unlimited freedom in dealing with sexual matters" in Rome with contemporaneous religious censorship. ${ }^{114}$

Schauer finds the Roman advent of Christianity in the fourth century as the point at which religious censorship began a gradual one-thousand year increase. ${ }^{15}$ This effort was said to have been given increased impetus by the invention of the printing press in $1428 .{ }^{116}$ Since printing made books available to all classes, the Church saw a need to increase control over blasphemous and heretical works. ${ }^{117}$

English obscenity law retained its tie to religion until the late seventeenth century. The 1663 case of The King v. Sir Charles Sedley is generally regarded as the first pure obscenity case. ${ }^{118}$ Even in that case,

111. Id. at 108.

112. Frederick F. SChaUer, The LAW OF OBSCENITY 1-2 (1976).

113. See id. at 1-2.

114. Id. at 2.

115. See id. at 2-3.

116. See id.

117. See id.

118. The King v. Sir Charles Sedley, 83 Eng. Rep. 1146 (K.B. 1663). See, e.g., SCHAUER, supra note 112, at 4; Leo M. Alpert, Judicial Censorship of Obscene Literature, S2 HARV. L. REV. 40, 40-41 (1938). 
however, the divorce from the religious basis of censorship in Sedley may be less than complete. Leonard Levy includes the case in his work on blasphemy and notes that while the reporters did not use the word "blasphemy," Sedley was said to have, along with other actions having a more modern obscenity caste, preached blasphemy, abused the scriptures, and preached a Montebank sermon. ${ }^{119}$

Sedley is, nonetheless, closer to modern obscenity law than its predecessors. ${ }^{120}$ Sedley, who was drunk, went out on the balcony of a London inn. He stripped naked, assumed a variety of immodest poses, urinated in bottles and then poured the bottles down on the crowd that had gathered below the balcony. That act caused a small riot. While Professor Schauer describes the case as the first in which "offensiveness to decency, apart from religious or political heresy, was an element of an offense against the state, ${ }^{121}$ the combination of sexual indecency, blasphemy and causing a breach of the peace make the basis for the conviction and the definition of obscenity open to debate..$^{122}$

According to Schauer, the 1727 case of Dominus Rex $v$. Curl ${ }^{123}$ finally established obscene libel as a common law crime. ${ }^{124}$ The conviction was for publishing the book Venus in the Cloister, or the Nun in Her Smock. While the book's dialogue on lesbian love was sexual, the setting was in a convent. Thus, it could also be viewed as an attack on religion. Schauer suggests that, because the anti-religious elements were anti-Catholic rather than antiChurch of England, they may be regarded as insignificant. ${ }^{125}$ On the other hand, Professor Alpert interprets the case as sustaining the indictment because of its attack on religion and, therefore, being triable in the common law courts. ${ }^{126}$

In American law, the early focus on the protection of religion is also apparent. When the Roth Court went in search of pre-Bill of Rights limitations on speech, it found blasphemy and heresy statutes. ${ }^{127}$ When the scope of obscenity law broadened in the post-Bill of Rights era, it still did not

119. See LeONARD W. LeVy, Blasphemy: Verbal OfFense AGainst the SACRED, FROM MOSES TO SALMAN RUSHDIE 214 (1993).

120. Accounts of the acts leading up to the case may be found in Alpert, supra note 118, at 41-42; SCHAUER, supra note 112, at 4; LEVY, supra note 119, at 214.

121. SCHAUER, supra note 112 , at 4 .

122. It is clear that it was not Sedley's nakedness and sexual poses alone that led to his conviction. His conviction was "for shewing himself naked in a balkony, and throwing down bottles (pist in) vi \& armis among the people in Convent Garden, contrà pacem and to the scandal of the Government." Sedley, 83 Eng. Rep. at 1146-47.

123. 93 Eng. Rep. 849 (K.B. 1727).

124. See SCHAUER, supra note 112 , at 6 .

125. See id. at 5.

126. See Alpert, supra note 118, at 44.

127. See Roth v. United States, 354 U.S. 476, $482-83$ (1957). 
focus solely on sex. Schauer finds it finally clear only with the decision of Swearingen $v$. United States ${ }^{128}$ in 1896 that obscenity and sex were necessarily tied together. ${ }^{129}$

What was it that led to the transformation of obscenity law from a body of law aimed at protecting religion to one focused on the prohibition of sexual representations? The usual explanations are found in the invention of the printing press, the increase in literacy among common people and the production of paperback books. Indeed, it does appear that increases in the censorship of pornographic works coincide with those technical and societal developments. Boccaccio's The Decameron, published in 1371, was one of the first printed books and has been called the "first work of modern pornography." 130 The new technology made books available to those who would not have been able to afford or obtain manuscript works. This new audience, less educated, and perhaps more corruptible, may have increased concern over the potential negative effects of some books.

The Decameron was placed on the Roman Catholic Church's index of forbidden books in the middle of the sixteenth century when that list was established as a reaction to the Reformation. ${ }^{131}$ The Church's concern was not solely over the sexual content of the book. Instead, it was due to the fact that the characters involved in the sexual stories were Catholic clerics. When the work was revised by changing monks to conjurors, nuns to noble women, an abbess to a countess and the Archangel Gabriel to a Fairy King, the book was removed from the forbidden list. ${ }^{132}$ The sexual content remained, and if there was concern over the widespread effects emanating from the printing press, the concern was aimed at weakening the faith of the common people rather than exposing them to pornography.

While works that combined pornography with unflattering portrayals of clerics or religion continued to be subject to prosecution, legal attacks on purely sexual material were of later vintage. The founding of the Society for the Suppression of Vice in England in 1802, and the attacks on pornography

128. 161 U.S. 446 (1896).

129. See SCHAUER, supra note 112, at 19.

130. H. MONTGOMERY HYDE, A HISTORY OF PORNOGRAPHY 65 (1964). It is interesting that the quick adoption of newer technologies by producers and distributors of sexual material is not purely a modern phenomenon limited to videotapes and the Internet. Even in technological advances preceding the printing press, such as the development of pottery, sexual images were among the first portrayed. See infra notes 141-43 and accompanying text.

131. See id. at 71,153 . The development of moveable type printing dates from the middle of the fifteenth century and may have increased concern over the cheaper availability of books. Thus, the time lapse between the publication of The Decameron and its placement on the forbidden list may not be so great as to make the invention of printing a plausible cause of concern. Nonetheless, the focus was on protection of the Church rather than on concerns over depictions of sexual activity.

132. See id. See also DAVID LOTH, The EROTIC IN LITERATURE 65-66 (1961). 
in the early nineteenth century, followed the Industrial Revolution's development of a new and literate middle class (another group that might prove more corruptible than the learned and noble). ${ }^{133}$ Similarly, the development of cheaper paperback books made pornographic materials available to a wider audience. While the wealthy might not have been corrupted by expensive books, cheap books were seen as troublesome. ${ }^{134}$

This explanation seems plausible with regard to some of the changes in societal attitudes toward, and the censorship of, sexual materials, but the explanation also seems lacking in certain respects. While the invention of the printing press may have corresponded to the Vatican's institution of its list of forbidden books, that list seems to have focused on heretical, rather than sexual, content. ${ }^{135}$ Furthermore, while the printing press and moveable type may have made books more widely available, prints and sketches did not have to await that invention, and sexual themes in pottery were already an ancient tradition. Sexual material, which may be even more evocative in pictorial form, had long been available to the masses. What the press made accessible were the more complex religious ideas that endangered the Church itself.

The technological explanation seems to be in better accord with the later changes. As Morris Ernst has noted, the inclusion of the written word in obscenity statutes that had previously only addressed pictures may be tied to an increase in literacy rates between the $1840 \mathrm{~s}$ and $1870 .^{136}$ It also seems plausible that the development of the paperback would have led to an increase in concerns that sexual materials may have a negative effect on the masses.

Nonetheless, the technological explanation is still unsatisfying. It explains only some of the changes in European and American societies' positions on sexual censorship. It also fails to explain the change in focus from heresy to sexuality as the target for such censorship. An explanation that ties more of the significant changes together would be an improvement. If that explanation can also bring together the themes of religion, degradation, and sex, it would seem superior to the theory previously offered.

\section{Religion, Sex and Degradation}

The early history of obscenity law and its focus on the protection of religion and the importance of degradation do indeed tie together. Religion

133. See HYDE, supra note 130 , at 165 .

134. See Morris L. Ernst, Introduction to H. MONTGOMERY HYDE, A History OF PORNOGRAPHY at vii, viii (1969).

135. See supra notes 130-32 and accompanying text.

136. See Ernst, supra note 134, at vii. 
regularly posits a special relationship between human beings and a God or the gods. Certainly, among all the religious traditions important to postclassical Europe or the Middle East, humans stand above the animals. Humans are seen as qualitatively different. Much of that difference is found in the existence of the soul. The soul is an aspect of humanity that makes us more like god than animals. Thus, an attack on religion is also an attack on the status of humans. If there is no God, humans cannot be like god and may not be inherently different from animals. An examination of the treatment of depictions of sex in various eras may also be included in the relationship between religion and degradation, thereby tying the three themes together.

\section{Classical Greece}

Greek society was very tolerant of sexual themes in the arts. As D. H. Lawrence declared, "some of Aristophanes shocks everybody today, and didn't galvanize the later Greeks at all." 137 The material spoken of is described as "bawdy blasphemy," and would not approach the sexual content of a modern "adult film." 138 However, in the not too distant past, some Greek drama would have shocked American society. Aristophanes' work is rife with sexual innuendo, prop phalluses, and some nudity. ${ }^{139}$ Aristophanes' play Lysistrata was subject to customs seizure during the first thirty years of this century and, as late as 1955 , was considered obscene by the United States Post Office. ${ }^{140}$

The painting and sculpture of classical Greece often had pornographic content. Representations of various forms of sexual intercourse are found in pottery of the era, "even . . . on the bottoms of children's drinking bowls and plates, so that they could have something amusing to look at when they were having their meals." 141 Phallic symbols were placed on street corners as places to pray for fertility, ${ }^{142}$ and "every Athenian home had a statue of Hermes, with his penis erect, before its front door." 143

Greek acceptance of pornographic arts and sexual themes in drama mirrored its view toward sexual activity. Except for women of the citizen

137. DAVID TRIBE, QUestions OF CENSORSHIP 32 (1973) (quoting D. H. LAWRENCE, PORNOGRAPHY AND OBSCENITY 5-6 (1929)).

138. See id.

139. See, e.g., ARISTOPHANES, THE Clouds (Benjamin Bickley Rogers trans., Oxford Univ. Press 1969) (423 B.C.); ARISTOPHANES, LYSISTRATA (Douglas Parker trans., 1964).

140. See Hyde, supra note 130 , at 40 (citing JAMEs C.N. PAUL \& MURRAY L. SCHWARTZ, FEDERAL CENSORSHIP 104 (1961)).

141. HYDE, supra note 130 , at 41.

142. See id.

143. Richard A. POSNER, SEX AND REASON 41 (1992). 
class, ${ }^{144}$ "the Greeks thoroughly enjoyed sex in all its sundry manifestations and felt not the slightest sense of shame about it."145 While female citizens may have been repressed, prostitution and concubinage, as well as the acceptance of certain homosexual relations, ${ }^{146}$ speak to a very active sexual culture.

The sexual activities of the Greeks were matched, or exceeded, by the sexual exploits of the Greek Gods. Zeus, the mightiest of the gods, engaged in rape, adultery, and pederasty. ${ }^{147}$ Prostitution was practiced by the priestesses at the temple of Aphrodite and was seen as religiously sanctioned. ${ }^{148}$ The festivals of Dionysus have been described as "wild sex orgies." 149 It is said that, when Phryne of Thespiae was on trial for the capital offense of corrupting the youth of Athens, her advocate had her stand up in court and tore off her robe, exposing "her beautiful breasts and figure ... to the public view." 150 The sight convinced the judges that the defendant had been divinely endowed by Aphrodite, and they found her not guilty.

For the Greeks, sex was not degrading. While questioning the relationship between man and the gods would not be tolerated, engaging in sex or depicting humans so engaged did not in any way weaken that relationship. The gods themselves were highly sexual, and human sexuality did not make humans more like animals than gods.

The themes of degradation, religion and sex tie together. Sex did not degrade. Sex and pornography did not have to be restricted to protect the relationship between man and the gods. Obscenity law, as a way to enjoin the degradation of humanity, could focus on direct heretical attacks on religion.

Not only did sexual appetite fail to distinguish humanity from the gods, but it also failed to raise concerns over the animal nature of humans. Sexual activity was divine, and just as human sexuality did not lead to any question of how close humans were to the gods, the animal side of divinity did not lead humans to assert their separation from the animals. Greece, with Aesop being of particular note, had a strong animal fable tradition, and "[i]t is most likely that any society that sees a close relationship between humans and animals, that sees a parallel between species, will produce fable-type stories

144. See id. at 39.

145. HYDE, supra note 130 , at 41 .

146. See POSNER, supra note 143 , at $42-43$.

147. See id. at 42.

148. See HYDE, supra note 130 , at 36 .

149. LOTH, supra note 132 , at 48.

150. HYDE, supra note 130 , at 34 . It appears that Phryne did not participate in the nudity which was common in the public baths or at the festival of Poseidon. See id. at 34-35. 
that explore the metaphorical relationship."151

\section{The Roman Era}

Roman theater treated sexual themes with at least as much toleration as had the Greeks. Professor Beacham's study of Roman drama compares the performances of Etruscan actors in Rome and the phallica - phallic ceremonies to assure fertility - of Greece. ${ }^{152} \mathrm{He}$ also notes the existence of terra cotta figures with oversized phalluses in those areas of Italy colonized by the Greeks and suggests early Roman performances of suggestive dances of a variety he characterizes as similar to modern "stag-parties."153

The liberal treatment of sex continued into later eras in Rome. Beacham notes that the Floralia festival performances were known for their license, merriment, and naked female performers. ${ }^{154}$ In fact, he finds an outlook on sex which is even less restrained than that of the Greeks. ${ }^{155} \mathrm{He}$ reports the "faithful reenactment" in late Roman theater of the legend of Pasiphae concealing herself in a false cow to be mounted by a bull. ${ }^{156} \mathrm{He}$ further reports that in the third century A.D., Elagabalus ordered that sexual scenes in performances not be simulated but be actually performed. ${ }^{157}$ Judge Posner makes the same point, noting the appearance on stage of nude women as actresses or dancers and the performance of sexual acts. ${ }^{158}$ With respect to literary works, Gaius Petronius' Satyricon has remained a classic of pornography. ${ }^{159}$

The actual sexual culture of the Romans also appears to have been more permissive, with citizen women more likely to participate, than the sexual culture found in Greece. ${ }^{160}$ Pederasty was common, as was male, female, and child prostitution, and often focused around public bathhouses. Because Roman culture was so strongly influenced by Greek culture, the similarity is not surprising. Since the Roman gods were also similar, or identified with the Greek gods, sexual activity by Romans would not have degraded the individual by separating human activity from that of the gods.

151. Joyce E. Salisbury, The Beast Within: ANimals in the Middle Ages 106 (1994).

152. See generally Richard C. Beacham, The Roman Theatre and Its Audience (1991).

153. See id. at 4-5.

154. See id. at 129.

155. See id. at 54.

156. See id. at 136.

157. See id. at 137.

158. See POSNER, supra note 143 , at 45.

159. For a description of the content of the Satyricon, see HYDE, supra note 130, at 5458.

160. See PoSNER, supra note 143 , at 44. 
In fact, in at least one case, sexual activity made an individual a god. When the emperor Hadrian's boy lover Aninous died, Hadrian deified him, and Aninous was widely worshiped. ${ }^{161}$

\section{The Early Christian Era}

The Christian era brought to European culture a profound change in view as to the nature of God. The individual gods in the panoply of Greek and Roman gods would be expected to interact with each other. Those gods had appetites, including rather healthy sexual appetites. Those who worshiped them, including priests and priestesses, would find nothing shameful in having the same appetites as, and emulating the practices of, the gods.

Judge Posner states that just as the advent of the Christian era brought a new view of God to European culture, it also brought a new view of man. ${ }^{162}$ The Christian and Jewish belief that humans are made in the image and likeness of God implies that there is some degree of divine nature in the human spirit. That divine nature can only be corrupted by the very existence of the body.

Man is a degenerate version of God, the degeneracy consisting not only in pride and envy and other spiritual flaws but also in the possession of a body that is prone not just to decay but to every sort of shame and indignity. The body . . . should be clothed, ideally at all times; for it is a shameful thing, a thing to be concealed, not flaunted in the manner of the Greeks and Romans. And bodily activities should be confined to those that are necessary. ${ }^{163}$

This change is not based solely on a different view of the nature of human beings. The Greeks could consider themselves god-like and still be sexually active because that was also the nature of the gods. As Posner notes, the Greeks may well have considered themselves more moral than the gods. ${ }^{164}$ However, the belief in a non-corporeal god, one without sexual urges or the need to eat and to eliminate, makes the existence in those urges and needs in humanity a measure of our distance from the divine nature. They identify us with the animals.

Thus, the task of the early Christian church was to examine the status of humans, and if humans were to share in the divine nature, they would

161. See id.

162. See id. at $45-46$.

163. Id. at 46.

164. See id. at 42. 
have to be distinguished from the animals. As Joyce Salisbury stated in her study of the relationship between humans and animals in the middle ages:

When early Christian thinkers established what they believed to be clear categories that separated animals from humans, they were not only making a theological statement of humanity's dominance over the natural world, but they were actually defining what it meant to be human. And as in so many things, it was easier to define humans by what they were not - animals - than by what they were. ${ }^{165}$

Sex was a major concern in the relationship and differentiation between humans and animals. Unlike animals, humans were seen to have the ability to reason, but sexual activity weakened the distinction.

Augustine as early as the late fourth century established the notion that during sexual intercourse "there is an almost total extinction of mental alertness; the intellectual sentries . . . are overwhelmed." If sexual intercourse banished reason, and if reason were the defining quality of humans, then sexual intercourse was bestial and threatened one's humanity. . . . The irrational passion implicit in the act of intercourse led Thomas Aquinas to say that "in sexual intercourse man becomes like a brute animal" and that insofar as people cannot "moderate concupiscence" with reason, they are like beasts. ${ }^{166}$

While not all activities engaged in by animals could be banned, the early Christian response was to confine animal-like activities to those that were necessary. ${ }^{167}$ It is necessary to eat, but it was seen as sinful to eat excessively. Sex is necessary to the survival of the species, but sex outside of marriage and nonprocreative sex generally were regarded as driven by animal appetites, serving to deny the human spirit, and were therefore sinful. Such sexual activity, viewed against the background assumption of a quasidivine human nature, was considered unnatural.

As Posner recognizes, sexual practice in the era was more liberal than the theory would allow. ${ }^{168}$ Old pagan fertility rites died hard.

In France as late as the fifteenth century the ancient rites were so

165. SALISBURY, supra note 151 , at 138.

166. Id. at 78-79 (quoting ST. AUGUSTINE, CITY OF GOD, at 577 (H. Bettenson trans., 1972) (1467); THOMAS AQUINAS, SUMMA THEOLOGICA $\Pi$, Q. 98, at 493-94 (Fathers of the English Dominican trans., 1957)).

167. See POSNER, supra note 143, at 46.

168. See id. at 49. 
much a part of the casual popular attitude toward sex that the Church reluctantly absorbed some of them. Thus a Feast of Fools was permitted on Epiphany with masking and dancing, singing and fooling, all so Dionysian that bishops admonished the celebrants who felt called upon to copulate to please wait until they got outside the church. ${ }^{169}$

The Church hierarchy may not have had unrealistic expectations of its lay members. The "good faith" doctrine provided that priests should not inform followers that their sexual practices were sinful, if the followers were likely to continue the practices. ${ }^{170}$ The assumption was that the knowledge of the practice's sinfulness would not bring it to an end, and continuing the practice in the face of that knowledge would be a mortal $\sin .{ }^{171}$

It would appear that the Church saw a significant gulf between divine nature and the morality of the average believer. If not fully accepted, that chasm appears to have been tolerated. The clergy, however, was another matter. If the clergy was to be closer to God, its control over the animal side of human nature should be greater. Even if the clergy acted on its sexual appetites and resisted the imposition of celibacy, ${ }^{172}$ the perception of the clergy had to be controlled to cement spiritual authority over the masses. Thus, the concern over The Decameron's depiction of the sexual exploits of monks and nuns reflected less a concern with sexual depiction generally than with its bringing the clergy down from the divine to the base animal level of the ordinary man or woman. As previously explained, when the characters were changed to members of the laity, the book was removed from the forbidden list. The new possibility of widespread circulation, because of the invention of the printing press, may have been a factor in the Church's action. However, it was not a general concern over the dissemination of sexual material that raised the concern. It was, instead, the possibility of the widespread publication of material depicting the clergy as more animal than divine that motivated the action against The Decameron.

Minimal concern over the sexuality of the common people, as compared to the concern over the sexuality and closeness to divinity of the clergy, is in accord with the view of the nature of those common people. In Marie of France's collection of the fables of the middle ages,

the peasants were uniformly shown as stupid. . . . [O]ne of the defining qualities of animals in the Middle Ages was their irrationality. Humans had reason, animals did not. By showing

169. LOTH, supra note 132, at 66.

170. See POSNER, supra note 143 , at 50.

171. See id.

172. See id. 
peasants as uniformly stupid and irrational . . . Marie subtly, yet powerfully, reduced their status to the borders of the bestial.

In addition to rationality, ... sexuality defines an animal.

From the twelfth century onward, peasant sexuality was linked more closely to that of animals than to the more cultured love of the nobility. . . . When ... [Andrew the Chaplain] considers peasants, . . . he says that peasants cannot really love because they have sex "naturally, like a horse or a mule." Therefore, he, like Marie, reduces peasants as a whole group to a position lower than human by denying them rationality and seeing the proof of that denial in his perception of the nature of their sexuality. ${ }^{173}$

Given the perceived difference between the nature of the peasant and of nobles, and even more so of the clergy, ${ }^{174}$ the Church's focus on protecting the status of the clergy as closer to the divine than the animal, while being less concerned over the description of the sexual activities of other classes, is understandable.

The concern in this era over obscenity views sexual activity as degradation and focuses on the effect of sexual activity on the question of whether man is closer to the divine or to the beast. The difference between obscenity in this era and in earlier eras is that, in the earlier era, there was not such a gulf between the gods and the beasts, at least in their sexual appetites. The depiction of human sexuality in the earlier era did not degrade because it did not separate human nature from the divine. By contrast, in the early Christian era, sexuality was seen as contrary to the divine nature. Because sexual activity was in the province of the beast, depiction of sexual activity presented a degrading view of humanity, a denial of humans sharing in any divine nature. While that might not raise any official concern when limited to the laity, any such degradation of the holiness of the clergy became a great concern.

While concern over sexual depictions may have followed the invention of the printing press, it is really the sixteenth century onset of the Reformation that brought the first official attempts at suppression. Concern over sex, per se, did not lead to that action. Rather, criticism of the Catholic Church as hypocritical, based on the difference between its official doctrine on sex and the practices of the clergy, put the Church in a defensive

173. SALISBURY, supra note 151 , at 153-54 (quoting ANDREAS CAPELLANUS, THE ART OF COURTLY LOVE 149 (1964)).

174. See id. at 171-72 (noting the saints' renunciation of sex to avoid becoming animal like). 
posture. ${ }^{175}$ The status of the clergy as being close to God demanded the suppression of material depicting the clergy as engaged in less than divine activity.

Sex was also but one aspect of concern over species ambiguity. If humans are distinguished from animals, the idea of species metamorphosis is discomforting. Tales of such changes often included sexual episodes, again establishing sex as the link between the human and animal worlds. ${ }^{176}$ However, any tale of species ambiguity or metamorphosis was of concern, leading such early Christian scholars as Ambrose, Augustine and Aquinas to address such pagan tales. ${ }^{177}$ For that reason the exhibition of a speciesambiguous being could be considered obscene, because obscenity arguably treats humanity as animal, rather than divine. That would serve as an explanation for the much later prosecution of Knowles for his exhibition of his "unnatural monster." 178 That "monster" raised the question of human nature as either animal or as sharing in divinity.

\section{The Enlightenment}

There appears to have been an increase in the publication of pornographic material in the 1740 s, a period that may be taken as the beginning of the "high period of the Enlightenment." 179 That growth came on the heels of a Reformation and a change in attitudes toward sex. The reformers argued that the clergy should be allowed to marry. If the clergy should marry, then sexual activity, at least of a procreative variety within marriage, must not be shameful. ${ }^{180}$ The Enlightenment went even further. The increase in erotic literature and art may be seen as the result of an Enlightenment change in the cultural understanding of nature: "sexual appetite was natural; repression of sexual appetite was artificial and pointless; and the passions might have a beneficial influence in making humans happy in this world. Sexual enlightenment was consequently a part of the Enlightenment itself." 181

Whatever the cause of the increase in pornographic publications, the secular courts began to take notice. The 1663 case of The King $v$. Sir

175. See POSNER, supra note 143 , at 51. "The Reformation attacked Catholic sex theory as too severe and Catholic sex practice as too lax." Id. See also supra notes 130-32 and accompanying text (discussing the Church's real interest in placing The Decameron on the forbidden list).

176. See SAlisBURY, supra note 151 , at 159-60.

177. See id. at 160-61.

178. See supra notes 103-11 and accompanying text for a discussion of Knowles.

179. LYNN HUNT, THE INVENTION OF PORNOGRAPHY: OBSCENITY AND THE ORIGINS OF MODERNITY, 1500-1800, at 33 (Lynn Hunt ed., 1993).

180. See POSNER, supra note 143, at 51.

181. HUNT, supra note 179 , at 34 . 
Charles Sedley ${ }^{182}$ is generally regarded as the first pure obscenity case. ${ }^{183}$ While the court was secular, there was, as was noted, still at least some religious basis for the prosecution. ${ }^{184}$ Leonard Levy includes Sedley in his book Blasphemy and notes that, while the case report did not use the word "blasphemy," Sedley was said to have preached blasphemy, abused the scriptures, and preached a Montebank sermon, as well as other actions with a more modern obscenity caste. ${ }^{185}$

In 1708, The Queen v. Read ${ }^{186}$ was the first actual prosecution for literary obscenity in a British secular court. ${ }^{187}$ The connection of obscenity and religion was, however, still present to the degree that the court rejected the idea of bringing indictments for obscenity. In dismissing the indictment, the court said, "[a] crime that shakes religion . . . as profaneness on the stage . . . is indictable . . but writing an obscene book, as that intitled [sic], 'The Fifteen Plagues of a Maidenhead,' is not indictable, but punishable only in the Spiritual Court." 188

The 1727 English case of Dominus Rex $v$. Curl $^{189}$ is said by Schauer to finally establish obscene libel as a common law crime. ${ }^{190}$ Curl involved a conviction for publishing the book Venus in the Cloister, or the Nun in Her Smock. The content of the book was a dialogue on lesbian love, and as was common in earlier works raising the concern of the religious establishment, its setting was in a convent. While this is precisely the issue that led to earlier bannings by the Church, the fact that the anti-religious elements were anti-Catholic rather than anti-Church of England makes it questionable whether the conviction in Curl was based on the protection of religion or was focused on sexual depictions instead. ${ }^{191}$

There were not many other prosecutions for obscenity in English courts throughout the remainder of the $1700 \mathrm{~s} .{ }^{192}$ John Wilkes was prosecuted in the 1760s for publishing his Essay on Woman, ${ }^{193}$ but Wilkes' prosecution was probably politically motivated. ${ }^{194}$ The real incentive to prosecute was

182. 83 Eng. Rep. 1146 (K.B. 1663). For a French version of the case see, Le Roy v. Sir Charles Sidley, 82 Eng. Rep. 1036 (K.B. 1663).

183. See, e.g., SCHAUER, supra note 112, at 4; Alpert, supra note 118, at 40-41.

184. See supra notes $118-21$ and accompanying text.

185. LEVY, supra note 119 , at 214.

186. 88 Eng. Rep. 953 (K.B. 1708), overruled by Dominus Rex v. Curl, 93 Eng. Rep. 849 (K.B. 1727).

187. See Alpert, supra note 118 , at 43.

188. Read, 88 Eng. Rep. at 953.

189. 93 Eng. Rep. 849 (K.B. 1727).

190. See SCHAUER, supra note 112 , at 6 .

191. See supra notes $123-26$ and accompanying text.

192. See SCHAUER, supra note 112 , at 6 .

193. See The King v. John Wilkes, 95 Eng. Rep. 737 (K.B. 1763).

194. See SCHAUER, supra note 112 , at 6 . 
another Wilkes publication - a satire exposing corruption in the government - depicting King George III as imbecilic and suggesting that the King's mother had been involved in an illicit relationship. ${ }^{195}$

In American law in the 1700 s, there was a similar lack of concern over pornography. When the United States Supreme Court, in Roth, surveyed the state of the law at the time of the Bill of Rights, it found only blasphemy and heresy statutes and some restrictions on public displays and shows of all varieties. ${ }^{196}$ The Court did find, and quote, a Massachusetts statute making it criminal to publish "'any filthy, obscene, or profane song, pamphlet, libel or mock sermon' in imitation or mimicking of religious services." ${ }^{197}$ Even in the statute, however, the focus was on the protection of religion, and obscenity was addressed only when used to mimic a religious service.

The increase in pornographic publications may be seen as a product of an increasing acceptance of humans as also being animals. Clearly, as seen in the heresy and blasphemy statutes, the denial of the existence of god, and its implicit rejection of any divine nature of humans, was unacceptable, but recognizing that humans also shared in the nature of the animals was less objectionable. ${ }^{198}$ The relationship to religion was also recognized by the pornographers themselves.

John Cleland, author of Fanny Hill, . . . and others like him were attracted to the religious and sexual representations of ancient Greece, Rome and India. They may have dreamed of inaugurating a new deistic, libertine religion of their own that included homoerotic rituals. A fraternity of this sort was established by Sir Francis Dashwood at Medmenham Abbey in the 1750s, although those who participated, including the notorious John Wilkes, insisted on its heterosexuality. Similar notions were taken up later in the century by Richard Payne Knight, who wrote extensively about the cult of Priapus as an alternative stamped out by the arrival of Christianity. ${ }^{199}$

With the exceptions noted, and those examples having a religious aspect, obscenity prosecutions were rare throughout the 1700s. Fanny Hill, or Memoirs of a Woman of Pleasure, was not prosecuted when published in

195. See Alpert, supra note 118 , at 44.

196. See Roth v. United States, 354 U.S. 476, 482 n.12 (1957).

197. Id. at 482 (quoting Acts and Laws of the Province of Mass. Bay, ch. CV, $\S 8$ (1712), Mass. Bay Colony Charters \& Laws 399 (1814)).

198. Salisbury finds the beginnings of the reacceptance of the classical relationship between humans and animals to have begun in about 1400. See SALISBURY, supra note 151, at 2. Perhaps the change occured somewhat earlier, as she notes the reemergence of humananimal transformation tales in the twelfth through the fourteenth centuries. See id. at 161 .

199. HUNT, supra note 179 , at 41. 
England in $1748,{ }^{200}$ although it became the focus of many prosecutions in the succeeding centuries. ${ }^{201}$ Pornography in that era escaped legal action, unless it had a seditious or blasphemous character. ${ }^{202}$

\section{The Victorian Era}

While the Victorian Era is seen as the period in which obscenity prosecutions became more common, the change in the acceptance of pornography began before the ascension of Victoria to the throne. In 1787, King George III issued a proclamation calling on the public "to suppress all loose and licentious prints, books and publications, dispensing poison to the minds of the young and unwary," ${ }^{203}$ and the Society for the Suppression of Vice was founded in England in 1802. ${ }^{204}$ Even then, however, there was less than a flood of obscenity prosecutions. The Society for the Suppression of Vice brought between thirty and forty prosecutions in its first fifteen years, ${ }^{205}$ and in England "[t]here were about three obscenity prosecutions a year . . in the first half of the 19th century."206

The reasons offered for this change are varied. Judge Posner suggests that sexual attitudes in England became more conservative as a reaction to French liberalization during an era of conflict between the two nations. ${ }^{207}$ Professor Hyde suggests that the end of the Napoleonic Wars resulted in a great increase in the amount of pornographic literature reaching England from the Continent, which led to an increased effort of suppression. ${ }^{208}$ This early concern over French sexual attitudes and Continental pornography was only the beginning of concern about French influence on English culture and morality.

From about 1866 onwards, the seemingly endless importation of morally questionable French literature gave rise to increasing pessimism over the drama and, in consequence, over the fate of English society. ... D During the late 1860 s and early 70 s there was a concerted campaign on the part of the licensing authorities

200. See SCHAUER, supra note 112 , at 6 .

201. See, e.g., John Cleland's Memoirs of a Women of Pleasure v. Massachusetts, 383 U.S. 413 (1966); Commonwealth v. Holmes, 17 Mass. 336 (1821).

202. See HYDE, supra note 130 , at 163 . Hyde also notes the execution of the author of The Whore's Rhetorick in France in 1644, but attributes the execution to the anticlerical character of his writing rather than to the pornographic nature of the work. See id. at 155.

203. Id. at 164 .

204. See id. at 165.

205. See id.

206. SCHAUER, supra note 112 , at 6.

207. See POSNER, supra note 143 , at 52.

208. See HYDE, supra note 130 , at 166. 
to ensure that as little as possible of the insidious corruption of French drama reached the London stage. ${ }^{209}$

Also commonly noted is the growth, as a result of the Industrial Revolution, of a literate middle class, a group that might be more susceptible to the negative effects of pornography than earlier aristocratic consumers. ${ }^{210}$ In addition, pornography became available to the lower classes because of the decreased cost of books. ${ }^{211}$

Whatever the origins of the initial reaction to the growth in pornography during the Enlightenment period, the exclusive concentration of obscenity law on sexual material developed in the 1860s. Professor Schauer notes the development of obscenity law between 1800 and 1860 but concludes that there was no definition of what was obscene in that era. ${ }^{212}$ The first definition of obscenity in English law is said to come out of the 1868 case of The Queen $v$. Hicklin. ${ }^{213}$ While that case does provide a definition of what varieties of sexual material are obscene, it must be admitted that there are earlier works of a purely sexual nature that were prosecuted as obscene. Hicklin might be seen as limiting the concept of obscenity to depictions of sexual activities.

Obscenity law developed somewhat later in the United States. Because the law developed slowly throughout the 1800 s, there were few prosecutions prior to the Civil War. ${ }^{214}$ In the years following the war, the attack on obscene publications intensified. Anthony Comstock founded the New York Society for the Suppression of Vice as a committee of the Y.M.C.A. in 1872 and as an independent organization in 1873. ${ }^{215}$ Similar organizations were established in other states, and in 1873 Comstock secured the congressional passage of a prohibition against mailing obscene material in a statute known as the Comstock Act. ${ }^{216}$ Comstock was appointed as a special agent for the Post Office and undertook to enforce the act. "In the first year after the law's passage, Comstock claimed to have seized 200,000 pictures and photographs; 100,000 books; 5,000 packs of playing cards; and numerous contraceptive devices and allegedly aphrodisiac medicines." ${ }^{217}$ In his career,

209. JOHN RUSSELl STEPHENS, THE CENSORSHIP OF ENGLISH DRAMA 1824-1901, at 8485 (1980).

210. See, e.g., HYDE, supra note 130 , at 165 .

211. See, e.g., POSNER, supra note 143, at 52 .

212. See SCHAUER, supra note 112 , at 7 .

213. 3 L.R.-Q.B. 360 (1868).

214. See SCHAUER, supra note 112 , at 12.

215. For a discussion of Comstock's role and the history of the statutes and prosecutions in which he was involved, see id. at 12-14.

216. An (Comstock) Act for the Suppression of Trade in and Circulation of Obscene Literature and Articles of Immoral Use, ch. 258, 17 Stat. 598 (1873).

217. SCHAUER, supra note 112 , at 13. 
Comstock claimed to have "convicted persons enough to fill a passenger train of sixty-one coaches, sixty coaches containing sixty passengers each and the sixty-first almost full. I have destroyed 160 tons of obscene literature." 18 In light of the minimal prosecutions in either England in the first half of the century or in the United States prior to the Civil War, the sudden post-war concern led to an incredible increase in the number of convictions, with Comstock himself being involved in the conviction of over 3,600 people.

What explains this concern with nonreligious obscenity beginning in the late 1700 s and growing to a crusade in the later half of the 1800s? The availability of cheaper books and French postcards and the literacy of lower and middle classes may have been factors, but they do not seem sufficient enough to explain the difference in attitude that developed in that era. Pornography had been widely available in other eras, at least as early as Greek pottery, without causing such a strong reaction. Even in the then recent past, concerns over pornography focused on its heretical character. But in the late 1700 s and the 1800 s, the attack broadened to pornography with no religious content. Given the earlier concerns over religion as the basis for regulating pornography, an explanation that continued to focus on religion would seem a better explanation than one focussing on technology or literacy if something occurred in that era to renew questions over the relationships among humanity, God and the animals.

The change that might serve as such an explanation is the development of the theory of evolution. While Charles Darwin's The Origin of Species was not published until 1859 , the theory had been developing for some time. Carl Linnaeus, working in the middle of the 1700s, had begun the study of taxonomy, the classification of all living things. ${ }^{219}$ While Linnaeus placed the human in its own genus as the only living species in the genus homo, he appears to have done so for other than scientific reasons. Looking back on that decision, he later wrote:

I demand of you, and of the whole world, that you show me a generic character . . . by which to distinguish between Man and Ape. I myself most assuredly know of none. I wish somebody would indicate one to me. But, if I had called man an ape, or vice versa, I would have fallen under the ban of all the ecclesiastics. It may be that as a naturalist I ought to have done so. 220

218. JAMES JACKSON KILPATRICK, THE SMUT PEDdLERS 35 (1960).

219. See Carl Sagan \& ANn DruYan, Shadows of ForgotTen Ancestors 273 (1992).

220. Id. at 274 (quoting letter from Carl Linnaeus, to J.G. Gmelin (Feb. 14, 1747), quoted in GEORGE SELDES, THE GREAT ThOUGHTS 247 (1985)). 
While the naturalism of the Enlightenment espoused the animal side of humanity and led to an increase in pornography, taxonomy was making too much of our status as animals.

While Linnaeus limited his efforts to classification, others speculated on the genesis of species. Charles Darwin's grandfather Erasmus Darwin, in his 1794 work titled Zoonomia, or the Laws of Organic Life, wrote:

[W] hen we revolve in our minds the great similarity of structure which obtains in all the warm-blooded animals as well as quadrupeds, birds, amphibious animals as in mankind, would it be too bold to imagine that all warm-blooded animals have arisen from one living filament (archetype, primitive form)? ${ }^{221}$

While Charles Darwin and Alfred Russell Wallace may have been the first to explain the mechanism by which species evolve, predecessors had already postulated the relationships among species. This speculation could not have gone unnoticed. Erasmus Darwin was sufficiently well known and well thought of enough to have been invited to become the physician of George III, ${ }^{222}$ whose proclamation against pornography began the era of obscenity prosecutions. ${ }^{223}$

Also preceding Charles Darwin was John Baptiste Pierre Antoine de Monet de Lamarck who, beginning in the late 1700s, developed his own theory to explain the evolution of species. His theory that organisms inherited the acquired characteristics of their ancestors was the same as that of Erasmus Darwin and was treated seriously by Charles Darwin. ${ }^{224}$ This theory, however, would eventually lose out to Charles Darwin's natural selection - survival of the fittest - theory.

In 1859, the watershed was the publication of The Origin of Species. ${ }^{225}$ This book was published shortly after a reading of papers by Darwin and Wallace setting forth their parallel, independently developed theories at a meeting of the Linnaean Society. Darwin's book made the theory of evolution widely available to the reading public, as the entire first printing rapidly sold. ${ }^{226}$ While The Origin of Species was somewhat circumspect with regard to the participation of humans in the evolutionary process, a subject that Darwin would address directly in the 1871 publication of The Descent of Man, the implications were clear. "His restraint fooled no one. . . .

221. Gerhard Wichler, Charles DarWin: The Founder of the TheORY of EVOLUTION AND NATURAL SELECTION 23 (1961).

222. See SAGAN \& DRUYAN, supra note 190, at 36. Erasmus Darwin declined the offer. See id.

223. See supra notes 203-06 and accompanying text.

224. See SAGAN \& DRUYAN, supra note 219 , at 38.

225. Charles DaRWIN, THE ORIGIN OF SPECIES (1859).

226. See SAGAN \& DRUYAN, supra note 219 , at 50. 
[T]here could be no reconciling The Origin with a literal rendition of Genesis."27 Moreover, it was not simply a refutation of the literal truth of a religious work; it spoke to the worth of mankind. James Rachels, the modern scholar of the philosophical implications of Darwinism, stated that the theory of evolution "undermines the traditional idea that human life has a special, unique worth."228

In Darwin's work, the Enlightenment's examination of science and the place of humans in the world led to conclusions that had an impact on the individual's self-perception. George Levine, who has studied the effects of evolutionary theory on novelists, notes the following:

[Darwin] can be taken as the figure through whom the full implications of the developing authority of scientific thought began to be felt by modern nonscientific culture. Darwin's theory thrust the human into nature and time, and subjected it to the same dispassionate and material investigations hitherto reserved for rocks and stars. ${ }^{229}$

The loss of dichotomy between humans and animals was paralleled to a loss of the clear distinction between good and evil characters in the Victorian novel.
All living things in Darwin's world are quite literally related, and, as he will say in a variety of ways, graduate into each other. Isolated perfection is impossible . . . . Fiction's emphasis on the ordinary and the everyday, its aversion to traditional forms of heroism and to earlier traditions of character 'types,' all reflect the tendency obvious in Darwin's world to deny permanent identities or sharply defined categories - even of good and evil. Note how rarely in Trollope or . . . in Eliot genuinely evil characters appear. Typical stories are of decline or of development . . . . 230

The impact of Darwin on the nonscientific world resulted in the questioning of human nature. The impact on the novel was a genre in which plots were not simply struggles between good and evil characters. Instead, the subject became the presence of good and evil in the individual, which represented a struggle between the divine nature and the animal nature of the individual

227. Id.

228. James Rachels, Created from animals: The Moral Implications of DARWINISM 4 (1991).

229. George Levine, Darwin and the Novelists: Patterns of Science in VICTORIAN FICTION 1 (1988).

230. Id. at 17. 
human being.

While it should be clear that Darwin shook the religious beliefs of the era, and that there was a strong religious reaction to the developing theory of evolution, it may not be clear why that reaction would focus on sex and lead to increased prosecution of obscenity. That argument requires the examination of an additional factor. Levine noted that, after Darwin, humans became the subject of "dispassionate and material investigations hitherto reserved for rocks and stars,"231 but the result was much worse. Humans were clearly distinct from rocks or stars, but what many had taken to be a clear distinction between people and animals was no longer so clear. In particular, the common understanding of Darwin's theory as holding that humans descended from apes would certainly raise old concerns over distinctions between humans and the other animals, especially other primates. Any insistence that, despite Darwin's theory, humans were in fact different would focus on separating our behavior from that of the apes.

The behavior of apes that seemed to most concern European culture was their sexual activity. One of the early studies of chimpanzees in the wild was that of Boston physician Thomas Savage. He noted that, while chimpanzees exhibit remarkable intelligence, "they are very filthy in their habits."232 That judgment of "filth" was based on observations of the sexual habits of the chimpanzee.

Chimpanzees have an obsessive, unself-conscious preoccupation with sex that seems to have been more than Savage could bear. Their zesty promiscuity may include dozens of seemingly indiscriminate heterosexual copulations a day, routine close mutual genital inspections, and what at first looks very much like rampant male homosexuality. ${ }^{233}$

It was, of course, not simply the activities of animals in the wild that caused such concern in Europe. Even the animals' continuation of such behavior when caged in a zoo might make viewers uncomfortable, but such observation would not lead to as strong a reaction as the suppression of obscene materials. What was important was what the observation of chimpanzee behavior said about humans. "If, say, ducks or rabbits with a penchant for sexual excess were under review, people would not have been nearly so bothered. But it's impossible to look at a monkey or ape without

231. Id. at 1 .

232. SAGAN \& DRUYAN, supra note 219 , at 270 (quoting Thomas $N$. Savage \& Jeffries Wyman, Observations on the External Characters and Habits of the Troglodytes Niger and on Its Organization, 4 B. J. NAT. HIST. (1943-44), quoted in ThOMAS H. HuXLEY, MAN's PLACE IN NATURE AND OTHER ANTHROPOLOGICAL ESSAYS (1901)).

233. SAGAN \& DRUYAN, supra note 219 , at 270. 
ruefully recognizing something of ourselves."234 Any religious reaction to Darwin would have to focus on the differences between humans and monkeys or apes and would include images or descriptions of humans engaged in the copulations or genital inspections so common to the chimpanzee.

One topic remains to be tied into the argument presented here. That topic is masturbation. Since masturbation and pornography often go together, attitudes toward the two would also seem likely to be similar in various eras. Indeed, that appears to be the case. The classical era was free in its attitude toward pornography and sex generally, an acceptance that carried over to masturbation. "Masturbation, to the Greeks, was not a vice but a safety valve, and there are numerous literary references to it, especially in Attic comedy."235 There is also no indication of negative attitudes surrounding masturbation in the Roman era. ${ }^{236}$ The general change in attitude towards sex that came with the onset of the Christian era reached masturbation as well. While sex was necessary for the maintenance of the human species, nonprocreative sexual activities were unacceptable. ${ }^{237}$

In the same era in which Linneaus was developing his taxonomy, concern over masturbation moved from the realm of the religious into the medical and scientific arenas. In 1758, the Lausanne physician S.A.D. Tissot published L'Onanisme, dissertation sur les maladies produites par la masturbation. ${ }^{238} \mathrm{He}$ argued that the human body was subject to continual wasting through any loss of fluids and particularly focused on the loss of semen. While such loss was necessary for procreation, frequent intercourse and nonprocreative emission were seen as dangerous, leading to

(1) cloudiness of ideas and sometimes even madness; (2) a decay of bodily powers, resulting in coughs, fevers, and consumption; (3) acute pains in the head, rheumatic pains, and an aching numbness; (4) pimples of the face, suppurating blisters on the

234. Id. at 272.

235. Reay Tannahill, SeX in History 98 (1980). See also Vern L. Bullough, SEXUAL VARIANCE IN SOCIETY AND HISTORY 99 (1976). "Masturbation was regarded as a natural substitute for men lacking opportunity for sexual intercourse, considerable reference to it appearing in the extant literature." Id. (footnote omitted).

236. See Vern L. Bullough \& Bonnie Bullough, Sin, Sickness, \& Sanity: A HISTORY OF SEXUAL ATTITUDES 56 (1977).

237. See supra notes 162-66 and accompanying text. See also Jean-Louis Flandrin, Sex in Married Life in the Early Middle Ages: The Church's Teaching and Behavioural Reality, in Western SEXUALITY: Practice AND PRECEPT IN PAST AND PRESENT Times 114, 114-15 (Philippe Ariès \& André Béjin eds., Anthony Forster trans., 1985); Bullough, supra note 235 , at 355 .

238. See BULlOUGH \& BUllough, supra note 236, at 59; Bullough, supra note 235 , at 498 . 
nose, breast, and thighs, and painful itchings; (5) eventual weakness of the power of generation, as indicated by impotence, premature ejaculation, gonorrhea, priapism, and tumors in the bladder; and (6) disordering of the intestines, resulting in constipation, hemorrhoids, and so forth. ${ }^{239}$

Women faced all the problems of men and additionally would be subject to "hysterical fits, incurable jaundice, violent cramps in the stomach, pains in the nose, ulceration of the matrix, and uterine tremors, which deprived them of decency and reason and lowered them to the level of the most lascivious, vicious brutes." 240

In the 1800 s, the list of maladies due to masturbation had grown, in the writings of the Battle Creek Sanatorium's Jon Harvey Kellogg, to include:

general debility, consumption-like symptoms, premature and defective development, sudden changes in disposition, lassitude, sleeplessness, failure of mental capacity, fickleness, untrustworthiness, love of solitude, bashfulness, unnatural boldness, mock piety, being easily frightened, confusion of ideas, aversion to girls in boys but a decided liking for boys in girls, round shoulders, weak backs and stiffness of joints, paralysis of the lower extremities, unnatural gait, bad position in bed, lack of breast development in females, capricious appetite, fondness for unnatural and hurtful or irritating articles . . . , disgust of simple food, use of tobacco, unnatural paleness, acne or pimples, biting of fingernails, shifty eyes, moist cold hands, palpitation of the heart, hysteria in females, chlorosis or green sickness, epileptic fits, bed-wetting, and the use of obscene words and phrases . . . , urethral irritation, inflammation of the urethra, enlarged prostate, bladder and kidney infection, priapism, piles and prolapsus of the rectum, atrophy of the testes, varicocele, nocturnal emissions, and general exhaustion. ${ }^{241}$

While some of the belief in these purported results can be explained by experience with the insanity accompanying the final stages of syphilis that would be more likely in promiscuous persons, ${ }^{242}$ it seems difficult to understand how all these, sometimes contradictory, results could be seen as due to masturbation. Nonetheless, at least with regard to the mental effects, the beliefs persisted to the point that "half of the 1959 graduates of a

239. BULlOUGH, supra note 235 , at 498.

240. Id.

241. Id. at 545.

242. See Bullough \& Bullough, supra note 236, at 59. 
Philadelphia medical school believed that mental illness is frequently caused by masturbation . . . [,and] one out of five faculty members of that school believed the same thing."243

What is particularly interesting here is the view that masturbation, and other sexual habits, would be passed on to offspring. Kraft-Ebing, the author of the 1886 work Psychopathia Sexualis, reported the case of a woman who regularly engaged in masturbation and two of her sons began the same practice at an early age. ${ }^{244}$ More generally, there was a belief that if those who engaged in sexual perversions had children, the children would be born with similarly perverted instincts. ${ }^{245}$ That analysis goes a step beyond sexual activity as a reminder that we are animals and even beyond a view of sexual degeneracy as signifying that the practitioner occupied a lower rung on the evolutionary ladder. ${ }^{246}$ This belief appears to invoke the theories of Lamarck on the inheritance of acquired characteristics. Sex not only exposes our animal side and separates us from God, but sex and masturbation, both of which may result from pornography, are inherited and progressive characteristics that may increase the distance between humans and God from generation to generation. This concern over degeneration to ape-like creatures mirrors one of the results of Dr. Savage's field study of the chimpanzees. He reported the belief of the indigenous population as to the origin of those creatures.

It is a tradition with the natives generally here, that they were once members of their own tribe: that for their depraved habits they were expelled from all human society, and, that through an obstinate indulgence of their vile propensities, they have degenerated into their present state and organisation. ${ }^{247}$

The tie between evolution and pornography continues into the present era. The suppression of sexually explicit material in the early to middle portions of the current century was matched by the suppression of the teaching of evolution. The prosecution of sexual depictions, even in serious

243. Edgar Gregersen, SeXual Practices: The Story of Human SeXuality 28 (1982) (emphasis in original).

244. See Bullough \& Bullough, supra note 236, at 63.

245. See Bullough, supra note 235 , at 547.

246. See id. at 640.

247. SAGAN \& DRUYAN, supra note 219 , at 270 (quoting Thomas N. Savage \& Jeffries Wyman, Observations on the External Characters and Habits of the Troglodytes Niger and on its Organization, 4 B. J. OF NAT. HIST. (1943-44), quoted in THOMAS H. HuXLEY, MAN's PLACE IN NATURE AND OTHER ANTHROPOLOGICAL ESSAYS (1901)). 
literature such as the work of James Joyce and D.H. Lawrence, ${ }^{248}$ matched the era in which states banned the teaching of evolution in public schools. ${ }^{249}$ In the latter half of the present century, the toleration of sexual depictions has increased greatly, to the point where Professor Sunstein asserts that, under the constitutional test for obscenity, "most people involved in the production of sexually explicit work have little to fear." 250 At the same time, it has become clear that states cannot ban the teaching of evolution, ${ }^{251}$ and attempts to counter the teaching of evolution with a requirement of an equal treatment of creation science have been declared unconstitutional. ${ }^{252}$ While the changes in state obscenity prosecution and in the treatment of antievolution statutes might be explained by the application of the First Amendment to the states, federal law has also addressed obscenity, ${ }^{253}$ and the increase in toleration exists in federal law as well. ${ }^{254}$

Society, in the later part of this century, simply has become more tolerant of pornography. At the same time, we have become more comfortable with evolution and what that theory says about our position between God and the animals. What is perhaps most telling is that the group, other than the MacKinnon-Dworkin school of feminists, which has taken the strongest stand against sexually explicit materials is also the group which has taken a strong stand against evolution. Segments of the Christian right still are concerned over what both schools of thought say about the divine nature of humankind.

The religious explanation for the availability and treatment of pornography seems superior to the technological explanation. It is consistent across the millennia. The religious explanation explains the more recent changes that occurred around the time of the invention of the paperback book or the earlier invention of the printing press. It also explains changes in the transition from the Greek and Roman eras to the Christian era and the focus of concern in these eras. Furthermore, it lacks the technological explanation's fault in relying on the form of pornography, rather than its prevalence. While printing may have made pornographic books more

248. For a discussion of the obscenity prosecutions directed at serious works of literature, See EDWARD DE GRAZIA, GIRLS LEAN BACK EVERYWHERE: THE LAW OF OBSCENITY AND THE ASSAULT ON GENIUS (1992).

249. See Scopes v. State, 289 S.W. 363 (Tenn. 1927).

250. SUNSTEIN, supra note 90 , at 211.

251. See Epperson v. Arkansas, 393 U.S. 97 (1968).

252. See Edwards v. Aguillard, 482 U.S. 578 (1987).

253. Roth $v$. United States contains a catalog of federal statutes addressing obscene materials. See Roth v. United States, 354 U.S. 476, at 481 (1957).

254. The Miller test applies to federal, as well as state, obscenity law and limits liability to stronger depictions than would have been obscene up until the middle of the century, when Lysistrata was considered obscene by the U.S. Post Office. See supra note 140 and accompanying text. 
available, pornographic pottery was widespread in early eras. A change in the medium is simply not as good an explanation for the change in attitude toward pornography as a change in religious view and the impact of pornography on that view.

\section{RECONSIDERING THE FEMINIST ATTACK ON PORNOGRAPHY, THE INDIANAPOLIS ORDINANCE AND CANADIAN STATUTE}

There are at least two possible avenues to follow from here. The history offered could be used to bolster arguments against having any obscenity exception at all. The strongest arguments against the obscenity exception have been based on the values of autonomy and self-expression. ${ }^{255}$ While those values are very important, their nineteenth-century libertarian genesis indicates that they need not necessarily be considered of constitutional dimension. The reason that they are strengthened by the history offered here is that the development of the concept of obscenity from religious views might be used to argue that the obscenity exception is a violation of the First Amendment's Establishment Clause.

The Establishment Clause argument should not, however, serve to void the obscenity exception. Whatever the origins of the obscenity exception, this article has suggested that the current focus has evolved to consider not how divine-like humans may be, but instead to insist that we are something more than purely animal. Whether that difference is expressed in terms of a soul or a human spirit, the result will be the same and will not depend on the adoption of a particular religious view. Neither should the religious origins mean that the continued existence of the obscenity exception is an establishment of religion. The best analogy for this situation would seem to be the Sunday closing laws. They clearly had a religious origin, but they came to have other purposes. They provide a common day of rest on the day that most would choose as their day off. Even when challenged by Sabbatarians, who would be religiously required not to work on Saturday and legally required not to work on Sunday, the Supreme Court refused to find a violation of the Establishment Clause. ${ }^{256}$ The religiously-inspired law had come to have a secular purpose. Here, too, the religious basis of recognizing the divine nature of humans has turned to a basis in human dignity which does not insist that the people have a divine nature but only that there is something that separates us from the animals.

Another avenue for analysis is to look at the MacKinnon-Dworkin ordinance struck down in Hudnut and the Canadian statute at issue in Butler in light of the preceding examination of the history of obscenity. That 
history demonstrates that it is the degrading effect of sexual images that has been the focus of attempts to limit such depictions. In eras in which sexuality was not viewed as degrading because it did not differentiate between humans and the Gods, pornography was accepted. As sex became a difference between humanity and divinity, and placed humans on the same plane as animals, pornography came under eccliastic scrutiny. As the boundary between humans and animals blurred, legal sanctions were imposed on obscene materials. In the present era, in which we are comfortable with our place in taxonomy, we still believe that, if not of a divine nature, we are something more than animals, or at least different from the other animals.

The Canadian statute, then, seems to stand on solid historical ground. If the historical basis of obscenity law is not the protection of religion but instead the prevention of the degradation of humanity by the sexual separation of humans and god, it is degradation that is the core of the concept. The objection to pornography was founded in eras in which such depictions positioned humans as more animal than divine. Pornography was seen as degrading. In the current era, the degradation that is most objectionable may be viewed not so much as that which makes humans less than divine but as that which makes us less than human. The Canadian emphasis on degrading or dehumanizing sexual images comports with this background. ${ }^{257}$

The Indianapolis ordinance may also not have been too far off target. The prurience and the shamefulness of some sexual images may be best explained by the treatment of the persons involved as less than human. While less than human may once have meant less than divine, and all explicit sexual images might have been shameful, less than human now means no more than animal. It is the sexual image that treats individuals as purely physical, without regard to any aspects of human spirit, that may be seen as shameful. The MacKinnon-Dworkin ordinance focused on images that depict:

the graphic sexually explicit subordination of women, whether in pictures or in words, that also includes one or more of the following:

(1) Women are presented as sexual objects who enjoy pain or humiliation; or

(2) Women are presented as sexual objects who experience

257. In the Canadian Statute, violent sexual images also are obscene, degrading and dehumanizing. See Criminal Code, R.S.C. ch. C-46, $\S 163$ (8) (1985) (Can.). For an argument that violence, without sex, is similarly degrading and obscene, see KEVIN W. SAUNDERS, VIOLENCE AS OBSCENITY: Limiting THE MEDIA'S FirST AMENDMENT PROTECTION 63-70 (1996). 
sexual pleasure in being raped; or

(3) Women are presented as sexual objects tied up or cut up or mutilated or bruised or physically hurt, or as dismembered or truncated or fragmented or severed into body parts; or

(4) Women are presented as being penetrated by objects or animals; or

(5) Women are presented in scenarios of degradation, injury, abasement, torture, shown as filthy or inferior, bleeding, bruised, or hurt 'in a context that makes these conditions sexual; or

(6) Women are presented as sexual objects for domination, conquest, violation, exploitation, possession, or use, or through postures or positions of servility or submission or display. ${ }^{258}$

While an obscenity statute could not bar all images, or even all sexual images that depict women in the ways indicated, an obscenity statute could accomplish some of the goals of the ordinance. In accord with Miller, the statute would have to define the sexual acts that may be obscene when treated in a patently offensive way. It would also have to provide that, if the work taken as a whole had serious literary, artistic, political or scientific value, it could not be held obscene. While this runs counter to the position that, if a woman is harmed, the other value of the work should not matter, ${ }^{259}$ the concession is necessary to adapt obscenity to address the issue.

The remaining aspect of Miller is a requirement that to be obscene, the work, taken as a whole and applying contemporary community standards, must appeal to the prurient interest. But history would indicate that the shameful aspect of the prurient interest is the treatment of people as less than people, and that is the focus of the ordinance's definition of pornography. The statute could require that those factors be taken into account in determining prurience. However, not all images fitting the definition in the ordinance would be found obscene. The depiction that combined the specified sexual activities with the degradation of women would have to go beyond community standards for such depictions. While some might wish to suppress magazines such as Playboy, because they depict women in a "position of display," community standards seem not to be offended by such publications.

This understanding of prurience can also explain the MacKinnonDworkin ordinance's provision that men who could "prove injury in the same way that a women is injured" would have available the same legal remedies. ${ }^{260}$ While it may be more common to treat women as less than full 
persons in pornographic films, men might also be treated in the same way. A film that so treats males should also be viewed as appealing to the prurient interest, if the depiction of the degrading sex exceeds community standards. Furthermore, if the film also lacks serious value and depicts specifically defined acts in a patently offensive way, it could be held to be obscene.

This approach certainly does not reach all the images that the MacKinnon-Dworkin ordinance was designed to reach; however, it does provide some of what the authors sought. It does recognize that it is degrading sexual images that should be the target of regulation. It shows that the factors the ordinance used to define pornography are historically justified as factors defining obscenity. Since obscene materials already lack First Amendment protection, there is no need to convince the courts to establish a new category of unprotected speech or to accept the harm caused by pornography as sufficient to overcome First Amendment protections. The argument, as presented herein, as to the proper focus of the prurience requirement, may well be an easier battle to win. 
